\title{
TRACHEOSTOMY IN PATIENTS WITH ISCHEMIC STROKE
}

\author{
Erdem YAKA*, Tuğçe MENGi**, Pembe KESKINOGLU*** \\ * Dokuz Eylül University Faculty of Medicine, Department of Neurology, İzmir, TURKEY \\ ** Niğde Training and Research Hospital, Neurology Clinic, Niğde, TURKEY \\ *** Dokuz Eylül University Faculty of Medicine, Department of Biostatistics and Medical Informatics, \\ İzmir, TURKEY
}

\begin{abstract}
INTRODUCTION: The prognosis for stroke patients that requiring mechanical ventilation is poor with mortality rates up to $80 \%$. Airway management in ischemic stroke patients is of great significance for achieving a better clinical outcome. After endotracheal intubation, tracheostomy is recommended if patients require long-term ventilation. In this study, it is aimed to present the outcomes of percutaneous and surgical tracheostomy in ischemic stroke patients that were monitored in Neurological Intensive Care Unit (NICU).

METHODS: Patients with ischemic stroke admitted to NICU and underwent tracheostomy were reviewed retrospectively. Age, sex, mechanical ventilation time prior to tracheostomy, timing of tracheostomy, complications related to tracheostomy and mortality/discharge state were recorded. Patients were categorized into two groups as percutaneous tracheostomy or surgical tracheostomy groups.

RESULTS: This study presents 76 patients with ischemic stroke that underwent tracheostomy procedure in NICU. Thirtynine patients were in percutaneous tracheostomy (PT) group and 37 patients were in surgical tracheostomy (ST) group. There was no significant difference between the two groups regarding tracheostomy complications and mortality rates. DISCUSSION and CONCLUSION: Based on our seven years of clinical experience, we conclude that PT can be performed at bedside in a short time and is associated with low complication rates. PT can be conveniently applied to indicate patients by neurologists (working in NICU) after proper training.
\end{abstract}

Keywords: Percutenous tracheostomy, ischemic stroke, neurological intensive care unit.

\section{İSKEMİK İNME HASTALARINDA TRAKEOSTOMI}

ÖZET

GİRIŞ ve AMAÇ: Mekanik ventilasyon gerektiren inme hastaları için prognoz \% 80'e varan mortalite oranları ile kötüdür. İskemik inme hastalarında daha iyi bir klinik sonuca ulaşmak için hava yolu yönetimi büyük önem taşımaktadır. Endotrakeal entübasyon uygulanan hastaların uzun süreli ventilasyona gereksinimi olduğu düşünülüyorsa, bu hastalara trakeostomi açılması önerilmektedir. Bu çalışmada Nöroloji Yoğun Bakım Ünitesi'nde (NYBÜ) izlenmiş olan iskemik inme hastalarındaki perkütan ve cerrahi trakeostomi sonuçlarının sunulması amaçlandı.

YÖNTEM ve GEREÇLER: NYBÜ'nde takip edilen trakeostomi uygulanmış iskemik inmeli hastalar retrospektif olarak incelendi. Tüm hastaların yaş, cinsiyet, trakeostomi öncesi mekanik ventilasyon süresi, trakeostomi açılma tarihleri, trakeostomiye bağlı komplikasyonlar, ölüm/taburculuk hali kaydedildi. Hastalar perkutan trakeostomi açılmış olanlar ve cerrahi trakeostomi açılmış olanlar olarak iki gruba ayrıldı.

BULGULAR: Bu çalışma NYBÜ'de trakeostomi açılmış 76 iskemik inme hastasını sunmaktadır. Perkütan trakeostomi (PT) grubunda 39 hasta, cerrahi trakeostomi (CT) grubunda 37 hasta mevcuttu. İki grup arasında trakeostominin komplikasyonları ve mortalite oranların açısından anlamlı fark yoktu.

TARTIȘMA ve SONUÇ: Yedi yıllık klinik deneyimlerimize göre PT, kısa sürede yatak başında uygulanabilen ve düşük komplikasyon oranları olan bir işlemdir. PT, endike hastalara nörologlar (NYBÜ'de çalışan) tarafından, uygun eğitimi aldıktan sonra, rahatlıkla uygulanabilir.

Anahtar Sözcükler: Perkutan trakeostomi, iskemik inme, nöroloji yoğun bakım ünitesi.

Corresponding author: Erdem Yaka, Prof. MD. Dokuz Eylül University Faculty of Medicine, Department of Neurology, İnciraltı, 35240 İzmir, TURKEY

Telephone: +902324124066 E-mail: erdmyk@gmail.com

Received: 27.08.2019 Accepted: 25.11.2019

This article should be cited as following: Yaka E, Mengi T, Keskinoğlu P. Tracheostomy in patients with ischemic stroke. Turkish Journal of Cerebrovascular Diseases 2019; 25 (3): 145-149. doi: 10.5505/tbdhd.2019.45822 


\section{INTRODUCTION}

Patients admitted to Neurological Intensive Care Unit (NICU) are generally under mechanical ventilation because they are intubated, or require additional procedures to maintain the airway open or require close monitoring because they are not in a sufficient conscious state to maintain their airway open (1). Approximately $24 \%$ of patients with acute ischemic stroke admitted to NICU's or stroke units require mechanical ventilation (2). Stroke patients with mechanical ventilation have poor prognosis with mortality rates varying between $40-80 \%(2,3)$. Airway management is of great importance to have a better clinical outcome.

Tracheostomy is preferred in severe stroke patients admitted to ICU whom are connected to mechanical ventilator because extubation is unlikely or high risk of extubation failure (4). Tracheostomy prepares patients for weaning from mechanical ventilation by facilitating airway maintenance and allowing lower airways secretion clearance (5). Tracheostomy procedure enables early termination of analgesia and sedation, which lead to an earlier active rehabilitation (5).

In critically ill patients, either surgical or percutaneous tracheostomy can be preferred. In our center, surgical tracheostomy (ST) is performed by Ear Nose Throat (ENT) surgeons in an operating room setting, whereas percutaneous tracheostomy (PT) is performed by neurologists at bedside in NICU. The present study presents the outcomes of percutaneous and surgical tracheostomy in patients with ischemic stroke admitted to NICU.

\section{MATERIAL AND METHODS}

The study population consisted of patients admitted to the NICU of Dokuz Eylül University Medical Faculty Hospital between July 2009 and September 2016. All patients enrolled this study were diagnosed with ischemic stroke upon anamnesis, clinical and radiological findings, and underwent tracheostomy procedure.

Age, sex, ischemic stroke treatment, initial Glasgow Come Score (GCS) following admission to NICU, mechanical ventilation time prior to tracheotomy, GCS prior to tracheostomy procedure, timing of tracheostomy procedure, the team performing tracheostomy procedure
(ENT/NICU physicians), complications that developed during or after the procedure, timing of complications, whether mechanical ventilation requirement persisted or not, and mortality/discharge state were recorded on the data collection forms. Patients were categorized into two groups: PT group and ST group.

Tracheostomy complications were categorized based on the time of complication development. Complications that developed within the first 24 hours after tracheostomy were categorized as early complications, those developing between 1 to 7 days were categorized as medium term complications, and those developing after the 7 th day were categorized as late complications (6). Early complications were defined as misplacement of tracheostomy tube outside the trachea, arrhythmia, hypotension, hypoxia/hypercapnia, loss of airway control, pneumothorax, acute surgical emphysema, serious bleeding, bacteremia, esophageal injury, cardiorespiratory arrest, tracheolaryngeal injury, airway contusion due to dilatational tracheostomy. Medium term complications were defined as persistent bleeding, displacement of the tube outside the trachea, emphysema, pneumothorax, obstruction of the tube, severe atelectasis, wound site infection/cellulitis. Late complications were defined as tracheo-innominate artery fistula, tracheomalacia, tracheal obstruction, loss of anterior tracheal cartilage, tracheo-esophageal fistula, severe aspiration, chronic articulation and deglutition disorder, and tracheo-cutaneous fistula (6). Bleeding caused by tracheostomy was classified into minor or major bleeding. Major bleeding was defined as persistence of bleeding despite compression or bleeding that required transfusion (7).

Statistical analyses were performed using SPSS 22.0 statistics package software. Categorical variables were expressed as frequency and percentage values. Continuous variables were expressed as mean and standard deviation for parametric data and as median (minimummaximum) for non-parametric data. Statistical analyses were made with t-test, Mann Whitney U test and chi-square test. $\mathrm{P}<0.05$ was accepted as statistically significant. 


\section{RESULTS}

A totally of 205 patients with either acute or subacute ischemic stroke were monitored in NICU while connected to mechanical ventilator. Tracheostomy was performed in 76 (37.1\%) patients. Of the patients that underwent tracheostomy, $51.3 \%(39 / 76)$ were in the PT group, whereas $48.7 \%(37 / 76)$ were in the ST group. There was no statistically significant difference between the PT or ST groups regarding distribution of sex (Male/Female: PT group, 22/17; ST group, 15/22; p=0.167) (Table I).

The type of tracheostomy performed was examined according to years. Between 2009 and $2011,90.9 \%(20 / 22)$ of the patients underwent ST, whereas between 2012 and 2016, 68.5\% $(37 / 54)$ of the patients underwent PT.

Mean GCS of whole study group after admission to NICU was 9.0 \pm 2.2 . Mean GCS in PT group was $9.5 \pm 2.3$ and $8.5 \pm 1.9$ in ST group. The mean GCS was not statistically significant different between the two groups after admission to NICU $(p=0,248)$. The level of GCS of the whole study group prior to tracheostomy procedure was $6.3 \pm 2.3$. The PT groups had a mean GCS of $6.4 \pm 2.1$, whereas the mean GCS levels in the ST group were $6.3 \pm 2.0$ There was no statistically significant difference between the two groups regarding mean GCS prior to tracheotomy $(\mathrm{p}=0.835)$.

Sixteen (21.1\%) patients diagnosed with acute ischemic stroke were treated with intravenous or intra-arterial thrombolytic treatment or mechanic thrombectomy. Of those patients, 8 were in PT group (20.5\%) and 8 were in ST group $(21.6 \%)(\mathrm{p}=0.906)$. Decompressive craniectomy was performed in 1 patient of the PT group (2.6\%) and in 3 patients of ST group (5.3\%). Mean mechanical ventilation time before tracheostomy was $18.6 \pm 9.3$ days (min-max days:445 ) in the whole study group. This duration in the PT groups was $16.4 \pm 10.1$ days (min-max days: 4$45)$ and 22.1 \pm 6.6 days (min-max day: 11-37) in ST group ( $t$ test: $p=0.013$ ). Tracheostomy was performed after an average of $8.8 \pm 3.8$ days from ENT consultation (median days: 8) (min-max days: 3-18).

Overall

tracheostomy-associated complication rate was $24.6 \%$ in the whole study group with $21.1 \%$ in PT group and $29.6 \%$ in ST group $(p=0.429)$. Distribution of the procedurerelated complications according to time is presented in Table II. All patients with early or medium-term complications had bleedings. Among patients with bleeding, 1 patient (ST group) also had pneumothorax, and 1 patient (PT group) had obstructed cannula. In one patient (ST group) with a late complication, loss of anterior tracheal cartilage was observed. Bleeding was the most frequently observed complication $(23.1 \%)$ (Table III). Four patients developed major bleeding. Two patients with bleeding from PT group received 1 unit of erythrocyte suspension (ES) and 2 patients from ST group received 2 units of ES.

Hemoglobin levels (pre- and posttracheotomy) were not significantly different in PT group or ST group. (PT group: mean hemoglobin levels (g/dL): pre-tracheotomy, 8.9; posttracheotomy: $8.8 \mathrm{~g} / \mathrm{dL}$; $\mathrm{p}=0.915$; ST group: mean hemoglobin levels $(\mathrm{g} / \mathrm{dL})$ : pre-tracheotomy, 9.75; post-tracheotomy: $9.8 \mathrm{~g} / \mathrm{dL} ; \mathrm{p}=0.727$ ).

A total of 9 patients were weaned from mechanical ventilator, 4 patients from PT group (10.8\%) and 5 patients from ST group (12.8\%). There was no statistically significant difference between the groups $(p=0.786)$.

Mortality rate in the NICU after tracheostomy was $47.4 \%(36 / 76)$ with $46.2 \%(18 / 39)$ in the PT groups and $48.6 \%(18 / 37)$ in the ST group $(p=0.828)$.

Table I. Age distribution in groups.

\begin{tabular}{|c|c|c|c|c|c|}
\hline Group & Median, n & Mean \pm SD & Min & Max & $\mathrm{P}$ \\
\hline * $\mathrm{ST}$ & 75 & $73.2 \pm 10.9$ & 50 & 91 & \multirow{2}{*}{0.126} \\
\hline †PT & 79 & $76.4 \pm 11.4$ & 29 & 82 & \\
\hline
\end{tabular}

*ST: Surgical tracheostomy

†PT: Percutaneous tracheostomy

Table II. Classification of tracheotomy-related complications according to time.

\begin{tabular}{|c|c|c|c|c|c|c|}
\hline & \multicolumn{2}{|c|}{${ }^{\dagger} \mathrm{PT}$} & \multicolumn{2}{|c|}{${ }^{*} \mathrm{ST}$} & \multicolumn{2}{|c|}{ Total } \\
\hline & $\mathrm{n}$ & $\%$ & $\mathrm{~N}$ & $\%$ & $\mathrm{n}$ & $\%$ \\
\hline $\begin{array}{l}\text { Early } \\
\text { complication }\end{array}$ & 1 & 2.6 & 3 & 11.1 & 4 & 6.2 \\
\hline $\begin{array}{l}\text { Medium-term } \\
\text { complication }\end{array}$ & 7 & 18.4 & 4 & 14.8 & 11 & 16.9 \\
\hline $\begin{array}{l}\text { Late } \\
\text { complication }\end{array}$ & - & - & 1 & 3.7 & 1 & 1.5 \\
\hline $\begin{array}{l}\text { Overall } \\
\text { complication }\end{array}$ & 8 & 21.1 & 8 & 29.6 & 16 & 24.6 \\
\hline
\end{tabular}


Table III. Properties of bleeding complication.

\begin{tabular}{lcc}
\hline & ${ }^{\dagger P T}$ & ${ }^{*} \mathrm{ST}$ \\
\hline Major bleeding, $\mathrm{n}$ & 2 & 2 \\
Minor bleeding, $\mathrm{n}$ & 6 & 5 \\
‡EST, units & 2 & 4 \\
Timing of bleeding, day & $4.0 \pm 2.3$ & $2.0 \pm 1.8$ \\
Timing of bleeding, min-max & $1-7$ & $1-6$ \\
\hline *ST: Surgical tracheostomy & & \\
†PT: Percutaneous tracheostomy & \\
†EST: Erythrocyte suspension transfusion & \\
DISCUSSION &
\end{tabular}

The frequency of tracheostomy application in the general ICU is about $10-15 \%$, whereas this rate increases to $35 \%$ for patients with stroke (4). In our study, tracheostomy rate in ischemic stroke patients was $37.1 \%$ which points out to the importance of tracheostomy in patients with ischemic stroke monitored in the NICU. Tracheostomy is often performed by surgeons, anesthesiologists and intensivists. However, neurologists treating patients in NICU can also perform tracheostomy (8). There are advantages of percutaneous tracheostomy performed by neurologists in the NICU such as unnecessary consultations and surgical delays (8). In our study, average time interval between ENT consultation and tracheostomy was $8.8 \pm 3.8$ days. Today, while there is ongoing debate about timing of tracheostomy in patients with stroke $(3,5,9,10,11)$, a delay of 9 days due to consultation process is a significant loss of time. It is recommended that enteral feeding is initiated early in mechanically ventilated stroke patients (12). It has been shown that enteral feeding is associated with reduced infectious morbidity, hospital stay length and multiple organ failure in critically ill patients (13). Interruption of enteral feeding can impair healing in critically ill patients (14). Feeding is interrupted before tracheostomy; and for patients in NICU, delays in the surgical procedure performed in operating room are not uncommon. In our study, the interval between ENT consultation and tracheostomy procedure (average $8.8 \pm 3.8$ days) includes the time lost for surgical delay. We did not evaluate the causes of surgical delay of each patient separately, which is one of the limitations of the present study. It should be noted that these surgical delays cause unnecessary occupation of the ICU bed, which leads to disputes between ENT surgeons and ICU physicians.

Tracheostomy guidelines recommend planning of the timing on an individual basis (7).The appropriate time for tracheostomy in patients with brain damage are best decided by neurologists (8). Because extubation criteria and tracheostomy indications are established different for stroke patients monitored in NICU's $(4,10)$. In our study, average interval between admission to NICU and tracheostomy was $18.6 \pm 9.3$ days.

For critically ill patients, the recommended standard method for tracheostomy is bedside PT, or ST when PT is anatomically not applicable (7). The advantages of PT include short procedure time at bedside, lesser tracheostomy complications such as stoma infection or bleeding, and less tissue damage due to minimal dissection (15). In our study, we found that ST was more preferred between 2009-2011, whereas PT increased during the later years. Ultimately, 51.3\% of patients underwent PT and $48.7 \%$ underwent ST.

Tracheostomy is superior to endotracheal intubation because it reduces dead space, airway resistance, respiratory workload and laryngeal damage caused by prolonged intubation $(4,7)$. Despite its advantages, tracheostomy is an invasive intervention and can cause various complications (15). Seder et al. found very low tracheostomy-related complications rates $(9 \%$ with ST and 8\% with PT) (8). Other studies found between 19 and 25\% tracheostomy-related complications rates in stroke patients $(15,16)$. In our study, tracheostomy-related complications rates were $24.6 \%$ (21.1\% with PT, and $29.6 \%$ with ST). The difference in tracheostomy-related complications rates is probably due to the way the studies defined complications associated with the tracheostomy procedure. Seder et al. only included bleeding that developed within 48 hours following tracheostomy and required blood transfusion as tracheostomy-related complication (8); whereas in our study, all incidences of bleeding (with or without blood transfusion) developing within 7 days of tracheostomy were evaluated as tracheostomy-related complication. Twenty-one percent of the patients in this study had tracheostomy-related bleeding. But only two patients developed bleeding within the first 48 hours and required transfusion. Stroke patients that undergoing tracheostomy should be closely 
monitored for bleeding because of the anticoagulant/antiaggregant therapy they receive. Studies should take this into consideration while defining the window for tracheostomy-related bleeding.

Studies that compared PT and ST in terms of complications found lower frequency of wound site infection with PT (7). On the other hand, transfusion-requiring bleeding, pneumothorax and tracheostomy-related mortality rates were found to be similar between PT and ST (7). In our study, pneumothorax was observed in 1 patient from PT group, and bleeding that required transfusion was observed in 2 patients from each of the PT and ST groups. We did not observe mortality related to tracheostomy.

Long-term follow-up studies provide inadequate data regarding late complications (7). In this study, only one patient had a late complication. However, the follow-up period of the present study was confined to the length of NICU stay, which is the other limitation of this study.

In our study, no significant difference was found regarding procedure-related complications and NICU-mortality rates ( $p>0.05$ ) between the ST group and the PT group. In addition, hemoglobin values were not significantly different before and after tracheostomy in neither of the groups ( $p>0.05)$. This demonstrates that PT is as safe as ST.

Based on our seven years of experience, we conclude that percutaneous tracheostomy can be performed at bedside to indicated patients by a proper-trained neurologist (working in NICU).

\section{REFERENCES}

1. Yaka E. Airway management and mechanical ventilation. Turkiye Klinikleri J Neurol-Special Topics 2015; 8(3):7177.

2. Santoli F, De Jonghe B, Hayon J, Tran B, Piperaud M, Merrer J, Outin H. Mechanical ventilation in patients with acute ischemic stroke: survival and outcome at one year. Intensive Care Med 2001; 27(7): 1141-1146.

3. Bösel J, Schiller P, Hook Y, Andes M, Neumann JO, Poli S, Amiri H, Schönenberger S, Peng Z, Unterberg A, Hacke W, Steiner T. Stroke-related Early Tracheostomy versus Prolonged Orotracheal Intubation in Neurocritical Care Trial (SETPOINT): a randomized pilot trial. Stroke 2013; 44(1): 21-28.

4. Bösel J. Tracheostomy in stroke patients. Curr Treat Options Neurol 2014; 16(1): 274.

5. Schönenberger S, Niesen WD, Fuhrer H, Bauza C, Klose C, Kieser M, Suarez JI, Seder DB, Bösel J; SETPOINT2-Study Group; IGNITE-StudyGroup. Early tracheostomy in ventilated stroke patients: Study protocol of the international multicenter randomized trial SETPOINT2 (Stroke-related Early Tracheostomy vs. Prolonged Orotracheal Intubation in Neurocritical care Trial 2). Int J Stroke 2016; 11(3): 368-379.

6. Irwin RS, Rippe JM: Irwin and Rippe's Intensive Care Medicine. Lippincott Williams \&Wilkins. 6th edition. 2008.

7. Madsen KR, Guldager H, Rewers M, Weber SO, KøbkeJacobsen K, White J; Danish Society of Anesthesiology and IntensiveCare; Danish Society of Intensive Care Medicine. Danish Guidelines 2015 for percutaneous dilatational tracheostomy in the intensive care unit. Dan Med J 2015; 62(3): B5042.

8. Seder DB, Lee K, Rahman C, Rossan-Raghunath N, Fernandez L, Rincon F, Claassen J, Gordon E, Mayer SA, Badjatia N. Safety and feasibility of percutaneous tracheostomy performed by neurointensivists. Neurocrit Care 2009; 10(3): 264-268.

9. Villwock JA, Villwock MR, Deshaies EM. Tracheostomy timing affects stroke recovery. J Stroke Cerebrovasc Dis 2014; 23(5): 1069-1072.

10. Schönenberger S, Al-Suwaidan F, Kieser M, Uhlmann L, Bösel J. The SETscore to Predict Tracheostomy Need in Cerebrovascular Neurocritical Care Patients. NeurocritCare 2016; 25(1): 94-104.

11. Mascia L, Corno E, Terragni PP, Stather D, Ferguson ND. Pro/con clinical debate: tracheostomy is ideal for withdrawal of mechanical ventilation in severe neurological impairment. CritCare 2004; 8(5): 327-330.

12. Wirth R, Smoliner C, Jäger $M$, Warnecke $T$, Leischker $A H$, Dziewas R; DGEM Steering Committee*.Guideline clinical nutrition in patients with stroke. Exp Transl Stroke Med 2013; 5(1): 14 .

13. McClave SA. Preface. The benefit of enteral nutrition (EN) on patient outcome in criticalcare is profound. Gastrointest Endosc Clin N Am. 2007;1 7(4): 23-25.

14. Rice TW, Swope T, Bozeman S, Wheeler AP. Variation in enteral nutrition delivery in mechanically ventilated patients. Nutrition 2005; 21(7-8): 786-792.

15. Lee YC, Kim TH, Lee JW, Oh IH, Eun YG. Comparison of complications in stroke subjects undergoing early versus standard tracheostomy. Respir Care 2015; 60(5): 651-657.

16. Gritsan A, Dovbish N, Gritsan G, Gazenkampf A. Safety of percutaneous tracheostomy in patients with stroke. Intensive Care Med Exp 2015; 3 (Suppl 1): A778. 